\title{
ESTA É MINHA CARTA AO MUNDO
}

Fernanda Mourão

\begin{abstract}
RES U M O
A partir da primeira carta de Emily Dickinson (1830-1886) a Thomas Higginson, que então seria seu "preceptor" e interlocutor para sempre, este texto propõe uma leitura da obra da escritora norte-americana a partir do biografema da carta e da ideia de sua obra como "carta ao mundo" - conforme um de seus mais famosos poemas -, com todas as implicações trazidas pelo termo, e à luz das teorias de Roland Barthes, Maurice Blanchot e Silvina Rodrigues Lopes, entre outros.
\end{abstract}

\section{PALAVRAS - CHAVE \\ Poesia, escrita, carta}

Saber que não se escreve para o outro, saber que as coisas que vou escrever não me farão nunca amado por aquele que amo, saber que a escritura não compensa nada, não sublima nada, que ela está precisamente aí onde você não está - é o começo da escritura. Roland Barthes

15 de abril de 1862

Sr. Higginson,

O senhor está tão intensamente ocupado para dizer se o meu Verso está vivo?

A Mente está, ela própria, tão próxima - não pode ver com clareza - e não tenho a quem perguntar -

Se o senhor achar que respira - e puder me dizer - eu sentiria imediata gratidão -

Se eu cometo o equívoco - que ousará dizer - me daria grande honra - com o seu gesto Incluo aí o meu nome - pedindo-lhe, se me faz o favor - senhor - de me dizer o que é verdade?

Que o senhor não me traia - é desnecessário pedir - já que a Honra é garantia dela mesma -

Ao introduzir The Complete Poems of Emily Dickinson, Thomas H. Johnson ${ }^{1}$ identifica algumas datas importantes na história literária americana durante o século

\footnotetext{
${ }^{1}$ Jonhson é o editor de The Complete Poems of Emily Dickinson, bem como de Selected Letters, ambas, edições usadas neste artigo. Todos os poemas e cartas de Dickinson (e a ela endereçadas) aqui apresentados são traduções minhas a partir das referidas edições, e poderão ser tratados pela numeração que nelas recebem.
} 
XIX. Uma delas seria 21 de agosto de 1837, quando Emerson, na ocasião da formatura da turma de Thoreau, apresenta seu "American Scholar", imediatamente aclamado pelo então jovem Oliver Wendell Holmes como "nossa Declaração da Independência intelectual." Outra poderia ser um dia de julho, em 1855, quando Walt Whitman coloca pela primeira vez em circulação, para um público restrito, cópias impressas de Leaves of Grass. Finalmente, outra data seria, inquestionavelmente, 15 de abril de 1862, quando Thomas Wentworth Higginson recebe essa primeira carta de Emily Dickinson, acompanhada de um cartão com seu nome, em lugar de assinatura, e quatro de seus poemas, entre os quais o que viria a ser um dos mais importantes de sua obra:



De fato, a importância da correspondência de Emily Dickinson com aquele que seria seu "preceptor" até o fim da vida não pode ser subestimada. Higginson seria, a partir daquela primeira carta, seu maior "público" e também aquele que levaria sua obra a público, embora apenas depois da morte da escritora - já que ele nunca se sentiria à vontade diante da "estranheza" daquela obra, como prenunciava aquele primeiro contato. Emily, contando então 31 anos, e já com uma produção de nada menos que trezentos poemas, escreve ao homem de letras profissional para perguntar se seus versos "respiravam". Higginson, na época, colaborava em diversos jornais escrevendo sobre Emerson, Hawthorne, Lowell, James, Helen Jackson (o único escritor - no caso, escritora - com quem Dickinson se correspondeu), Whitman, Longfellow, Poe etc.

Emily toma a iniciativa de escrever a Higginson ao ler, no Atlantic Monthly, seu artigo intitulado "Letter to a Young Contributor" que oferecia conselhos práticos para os jovens escritores desejosos de iniciar uma carreira. Higginson era conhecido como um pensador liberal e interessado na condição da mulher, particularmente da mulher escritora. Em seu artigo de jornal, declarava sua satisfação em poder trazer a público novos talentos. Contudo, não esperava ser convocado a comentar e endossar o trabalho de um talento completamente novo, como aqueles primeiros poemas recebidos o revelavam. O mesmo estranhamento e a atração provocados pela primeira carta de Emily acompanhariam Higginson por toda a vida. Em 1891, ele escreve um artigo descrevendo o início de sua correspondência com a escritora:

\footnotetext{
${ }^{2}$ Poema 216: "Safe in their Alabaster Chambers - / Untouched by Morning - / And untouched by Noon - / Lie the meek members of the Resurrection - / Rafter of Satin - and Roof of Stone! // Grand go the Years - in the Crescent - above them - / Worlds scoop their Arcs - / And Firmaments - row - / Diadems - drop - and Doges - surrender - / Soundless as dots - on a Disc of Snow -" Os outros três poemas são o 318 , o 319 e o 320 .
} 
A impressão de um gênio completamente novo e original foi clara em minha mente na ocasião da primeira leitura daqueles quatro poemas como o é ainda agora, depois de trinta anos de um maior conhecimento; e com aquela impressão veio o problema, até hoje não resolvido, de qual lugar seria reservado na literatura para o que é tão impressionante e ao mesmo tempo tão indefinível à crítica. ${ }^{3}$

De fato, sua obra resistiria desafiando uma crítica disposta a encontrar, a qualquer preço, indícios na vida da escritora que pudessem "justificar" sua escrita tão peculiar, em uma interpretação biográfica baseada na imediata relação vida-obra. Sem sucesso, muitas vezes essa crítica terminou por concordar com o fato de que "é difícil determinar precisamente 'sobre o que' essa poesia nos fala." ${ }^{4}$

Se não conseguimos compreender Emily Dickinson através de sua vida pessoal, tampouco a época literária em que viveu nos é elucidativa nessa tarefa. Quem eram os contemporâneos de Emily? Ao lado de Walt Whitman, Emily é apontada como a maior poeta na literatura americana do século XIX. Mas quais teriam sido suas "influências"? Também Higginson, ao se deparar com sua poesia, quis sabê-lo. E eis a resposta que recebe, entre outras sobre idade, família, educação:

Sr. Higginson,

Sua delicadeza exigira gratidão imediata - mas estive doente - e escrevo hoje, na cama. Obrigada pela cirurgia - não foi tão dolorosa como eu supunha. Trago-lhe outros [poemas] - como o senhor me pede - embora eles pareçam não diferir - Enquanto meu pensamento está despido - Eu posso fazer a distinção, mas quando os coloco na Toga - eles parecem semelhantes, e entorpecidos.

O senhor perguntou quantos anos eu tinha? Não fiz versos - apenas um ou dois - até este inverno - senhor.

Vivi um terror - desde setembro - não poderia contá-lo a ninguém - e então eu canto, como o Menino canta em torno das Sepulturas, porque tenho medo - o senhor pergunta sobre meus Livros - Por Poetas - Tenho Keats - e Sr. e Sra. Browning. Em Prosa - Sr. Ruskin - Sir Thomas Browne - e o Apocalipse. Entrei para a escola - mas, por assim dizer - não tive educação. Quando Menina, tive um amigo, que me ensinou a Imortalidade mas aventurando-se muito perto, ele próprio - nunca retornou - Logo depois, meu tutor morreu - e por vários anos, meu Léxico - foi meu único companheiro - Depois encontrei mais um - mas ele não me quis como discípula - e então deixou o Terreno.

O senhor pergunta sobre meus Companheiros, Colinas - senhor - e o Pôr-do-Sol - e um Cão - tão grande como eu, que meu Pai me trouxe - Eles são melhores que Pessoas porque sabem - mas não contam - e o barulho no Poço, ao Meio-dia, supera meu Piano. Tenho um Irmão e uma Irmã - Minha Mãe não dá importância ao Pensamento - e o Pai, muito ocupado com seus Relatórios - para perceber o que fazemos - Ele me compra muitos Livros - mas implora para que eu não os leia - porque teme que eles perturbem a Mente. Eles são religiosos - exceto eu - e cortejam um Eclipse, toda manhã - que eles chamam de "Pai". Mas temo que minha história o fatigue - Eu gostaria de aprender - o senhor poderia me ensinar como crescer - ou é intransmissível - como Melodia - ou Bruxaria?

O senhor fala do Sr. Whitman - nunca li seu Livro - mas me foi dito que ele é infame De Miss Prescott, li "Circunstância", mas o texto me seguiu, na escuridão - então eu a evitei -

${ }^{3}$ JOHNSON. Introduction, p. 6. (Tradução minha)

${ }^{4}$ WOOLF. Emily Dickinson, p. 140. 
Dois Editores de Jornais vieram até a Casa de meu Pai, este inverno - e me perguntaram sobre minha Mente - e quando lhes perguntei "Por quê", disseram-me que sou digna de pena - e eles usariam isso para o Mundo -

Não poderia mensurar-me a mim mesma - Eu mesma -

Meu tamanho senti pequeno - para mim - Li seus Capítulos no "Atlântico" - e senti orgulho do senhor - Estava certa de que o senhor não recusaria uma questão confidencial É isto - senhor - o que pediu para lhe contar?

Sua amiga,

E- Dickinson ${ }^{5}$

Emily Dickinson dá uma ideia de sua existência até então. Vaga ideia, entretanto, que traz apenas traços de vida, menção a alguns nomes, uma atenção especial ao cão Carlo, ao que parece, com quem tinha mais afinidade na casa, e ao qual se refere em várias cartas -, os livros - não tanto os autores -, a relação difícil com a mãe e o pai, e desde já os editores. Sobre sua idade, vale comentar o trecho "O senhor perguntou quantos anos eu tinha? Não fiz versos - apenas um ou dois - até este inverno - senhor”. Quando escreveu a Higginson, aos 31 anos, Emily Dickinson contava com uma produção de trezentos poemas aproximadamente e, nem pela quantidade, nem pela qualidade, e nem por sua idade poderia ser considerada uma "novata". Entretanto, esse número estava ainda longe de alcançar o total de sua obra, já que, somente naquele mesmo ano de 1862, ela escreveria pelo menos outros 366 poemas. ${ }^{6}$ Emily sempre escrevera, mas a partir dos 28 anos, e conforme seu talento amadurecia, a escritora isolou-se cada vez mais em casa, passou a vestir-se quase sempre de branco e, nas raras ocasiões em que recebia visitas, conversaria apenas através de sua porta entreaberta. Ela teria, a partir de então, cada vez mais consciência de seu trabalho de escrita. De fato, o período de 1858 a 1861, culminando precisamente com a decisão de enviar seus poemas à apreciação de Higginson, no início de 1862, é de suma importância para sua consolidação como poeta:

Este é, finalmente, o período em que ela começava a se pensar como alguém que poderia escrever para a posteridade. A troca de cartas com Sue, sobre o poema do "Alabastro", que ocorreu do meio pro fim do verão de 1861, parece ter sido sua primeira tentativa de consulta sobre a sua poética. A próxima e última acontece em abril de 1862, quando inicia uma correspondência com T. W. Higginson. Os anos de 1858 a 1861 são um período em que suas forças se reuniam e o fluxo de seu talento aumentava a cada dia. ${ }^{7}$

Assim, quando fala de sua idade como não tendo feito mais que um ou dois versos até então, poderíamos ver talvez uma Emily que começa agora a nascer como poeta -

\footnotetext{
${ }^{5}$ Carta 261, em 25 de abril de 1862.

${ }^{6}$ Ao morrer, Emily deixa, nas gavetas do quarto onde viveu reclusa em sua escrita, 1.775 poemas organizados em pacotinhos, novecentos deles copiados a tinta em sessenta pequenos "fascículos", como foram chamados - folhas de papel meticulosamente dobradas e costuradas. Muitos outros poemas foram encontrados, ainda, escritos em papéis de diferentes formas e tamanhos, envelopes usados, páginas de cadernos e folhas de receitas. Uma meia dúzia deles foi publicada quando Emily era viva, por amigos que os receberam em cartas, à revelia da escritora.

${ }^{7}$ DICKINSON. Selected Letters, p. 140. (Tradução minha). O poema do "Alabastro" (216), um dos primeiros quatro enviados a Higginson, tem ao menos três versões, entre 1859 e 1861 . Aqui, opto pela $2^{\underline{a}}$ delas, com base na troca de correspondência entre Emily e a cunhada Sue. A respeito, ver DICKINSON. Selected Letters, p. 161-163.
} 
que agora começa a se ver como tal -, a ter consciência daquela voz que passa a se inscrever na literatura - o que pode ser evidenciado pelo fato de que, após o início de sua correspondência com Higginson, ela por vezes assinou suas cartas como simplesmente "Dickinson", supostamente pensando si mesma como um nome público.

Ao receber aquela carta, como vemos, longe de encontrar uma luz à qual pudesse ler Dickinson e seus poemas, Higginson se vê, como haveria de ser sempre, diante do intocável, do inapreensível. Mas não resiste à pronta tentação de "corrigi-los" intervenções "cirúrgicas" a que a escritora se refere sem mágoas, mas não sem ironia. A pedido de Higginson, Emily inclui na segunda carta outros poemas, prevenindo-o sobre o que leria, já que eles não pretendiam ser diferentes... Sem conseguir penetrar em seu mundo, em sua escrita, supõe-se que Higginson a tenha aconselhado a não publicar. Se ele nunca disse que seus versos não "respiravam" (ele próprio viveu do seu sopro) - que era o que em suma ela precisava saber - também não lhe poupou da impressão de que aquela respiração era descompassada, "descontrolada", "espasmódica" - inapropriada para o que se esperava na época. Ao que ela responde, sem anexar nenhum poema desta vez:

Querido amigo.

Sua carta não me causou Embriaguez, porque já provei Rum antes - Domingo chega apenas uma vez - embora até hoje tenha tido poucos prazeres tão profundos quanto sua opinião e, se eu tentasse lhe agradecer, minhas lágrimas me travariam a garganta -

Perto de morrer, meu Tutor me disse que ele gostaria de viver até que eu me tornasse poeta, mas a Morte foi hábil Ladra para que eu pudesse vencê-la - então - E quando longe, depois - uma luz repentina nos Pomares ou uma mudança de ventos perturbou minha atenção, senti uma pontada, aqui, - os Versos apenas aliviam -

Sua segunda carta surpreendeu-me e, por um momento, balançou - Eu não o supunha. Sua primeira - não ofendeu, por causa da Verdade - não tenho vergonha - Agradeço-lhe por sua justiça - mas não poderia calar os sinos que, tinindo, acalmaram minha Marcha Talvez o Bálsamo fosse melhor, já que o senhor sangrou-me antes -

Sorrio quando o senhor sugere que eu adie a "publicação" - estando isto tão longe do meu pensamento, como o Firmamento dos Peixes -

Se a fama me pertencesse, eu não conseguiria fugir a ela - se assim não fosse, o mais longo dos dias seria gasto em seu encalço - e eu perderia a aprovação do meu Cão - assim minha Ordem-Descalça é melhor -

O senhor pensa meu passo "espasmódico" - Estou em perigo - senhor -

O senhor me pensa "descontrolada" - Não tenho Tribunal.

O senhor teria tempo para ser o "amigo" de que o senhor pensa que preciso? Minha forma é pequena - não entulharia sua Escrivaninha - e não sou tão barulhenta como o Rato que morde suas Coleções - Se eu pudesse trazer para o senhor o que faço - não tão freqüente que chegasse a importuná-lo - e perguntar-lhe se fui clara - isso seria controle, para mim O Marinheiro não pode ver o Norte - mas sabe que a Agulha pode -

A "mão que me estende no escuro", ali coloco a minha, e vou-me embora - não tenho mais Língua, agora -

Como se eu pedisse uma simples Esmola,

E, em minha mão surpresa,

Um Estranho prensasse um Reino,

E eu, confusa, suportasse -

Como se eu pedisse que o Oriente

Trouxesse a Manhã, para mim -

E ela abrisse seus Diques de Púrpura,

A me espatifar com Aurora! 
Mas, o senhor seria meu Preceptor, Sr. Higginson?

Sua amiga,

E. Dickinson $-^{8}$

Ao referir-se com nítida ironia à questão da publicação - como algo tão distante de seu pensamento quanto o céu da terra - essa carta revela que, a partir de então - se assim já não era antes - a escrita, tanto de cartas quanto de poemas, passa a ter para Emily um sentido outro que não o de comunicar - seja ao público, seja aos amigos -, que não o de dar-se à compreensão de um outro. Mais ainda, a prontidão de suas respostas às críticas de Higginson demonstra o distanciamento de quem há muito já tinha para si uma posição bem definida - sua ordem-descalça - em relação à fama e ao estatuto do autor, e que era muito diferente do que se esperava do escritor - especialmente da mulher escritora - da época.

"A ilusão da comunicação intersubjectiva está na base de grande parte dos discursos justificativos da produção ou da publicação de cartas," diz Silvina Rodrigues Lopes, ${ }^{9}$ para comentar a mesquinhez da exploração do íntimo que o gênero suscita. É a natureza íntima da correspondência, segundo a autora, o que justifica em grande parte o interesse por ela, demonstrando o gosto pela "exploração do íntimo", a "vontade de devassa" de um público ávido por novidades, mas que, diria Blanchot, "antes de ler já leu": "O que é público não tem precisamente necessidade de ser lido; é sempre já conhecido, antecipadamente, de um conhecimento que sabe tudo e não quer saber nada."10

Ainda que assim se quisesse, Emily Dickinson não permitiria tal leitura de suas cartas, mesmo porque a natureza de sua escrita chega a impossibilitar a distinção de gêneros - "gênero não me pega", diria talvez, antecipando Clarice. ${ }^{11}$ Em muitas cartas, como na citada acima, por vezes temos dúvida sobre onde termina a carta e onde começa o poema - ou mesmo se toda a carta não é um grande poema, assim como seus poemas seriam uma grande carta.

Além disso, quem recorresse a sua correspondência como um material puramente biográfico, fatalmente voltaria de mãos vazias, pois o que dizer, como figurar uma escritora que, tendo uma só vez se deixado fotografar por um daguerreótipo, agora se apresenta assim, na próxima carta a Higginson, em resposta ao provável pedido de um retrato seu?

O senhor me veria - sem? Não tinha aqui nenhum retrato, mas sou pequena, como o Rouxinol, e meu Cabelo é cheio, como o Ouriço da Castanheira - e meus olhos, como Sherry no fundo do copo, deixado pela visita - Isso servirá?

O que sempre preocupa meu Pai - Ele diz que a morte pode ocorrer, e que ele tem Moldes para todo o resto mas nenhum Molde meu, mas eu notei que os Vivos rapidamente dispõem dessas coisas, e antecipam a desonra - O senhor não veria aqui um capricho meu O senhor disse "Sombrio". Conheço a Borboleta - e o Lagarto - e a Orquídea Não são estes também seus Compatriotas?

Estou feliz por ser sua aluna, e merecerei sua gentileza, que não posso retribuir.

\footnotetext{
${ }^{8}$ Carta 265, em 7 de junho de 1862.

${ }^{9}$ LOPES. Literatura, defesa do atrito, p. 135.

${ }^{10}$ BLANCHOT. O livro por vir, p. 258.

11 "Inútil querer me classificar: eu simplesmente escapulo não deixando, gênero não me pega mais." LISPECTOR. Água viva, p. 17.
} 
Se o senhor permite, repito a lição, agora -

O senhor me dirá minha falta, franco como a si mesmo, pois prefiro o susto, que a morte

- Não se chama o Cirurgião para aprovar - o Osso - mas para emendar, e a fissura interna, senhor, é mais crítica. E por isso, senhor, devo trazer-lhe - Obediência - a Flor do meu Jardim, e toda a gratidão que eu conheça. O senhor talvez esteja a rir de mim. Não posso parar por isso - meu Trabalho é a Circunferência - Uma ignorância, não de Costumes, mas se for pega pela Aurora - ou se o Pôr-do-Sol me vir - eu mesma o único Canguru em meio à Beleza, senhor, por favor, pois que isso me aflige, e pensei tal instrução talvez pudesse me livrar.

Porque o senhor tem muito trabalho, além do meu crescimento, e deve me dizer, o senhor mesmo, quão freqüente devo vir - sem inconveniência. E se a qualquer tempo arrepender-se de me ter recebido - ou se eu me mostrar feita de material diferente do que supunha - deverá banir-me -

Quando me coloco, a mim mesma, como a Representante do Verso - isto não quer dizer - eu - mas uma pessoa suposta. O senhor está certo, sobre a "perfeição."

O Hoje faz o Ontem significar.

Falou-me de Pippa Passes - nunca ouvi falar de Pippa Passes - antes.

O senhor vê que minha postura é de despreparo.

Agradecer-lhe me desconcerta. O senhor é completamente poderoso? Tendo eu prazer que o senhor não tenha experimentado, poderia com satisfação trazer-lhe.

Sua aluna. ${ }^{12}$

Emily não se dá à decifração. Ao negar-lhe uma fotografia, ${ }^{13}$ e enviar, ao invés, tal "descrição" sua, Emily reforça ainda mais o sentimento de Higginson de estar diante de um ser que, se ele não se apressasse a ir ver, não deixaria nenhum molde - mas apenas pequenos rastros - restos - de sua existência no mundo: a lembrança dos olhos num copo de xerez, dos cabelos num ouriço, da pequena figura fugidia num rouxinol. Por isso, mesmo após tantos anos de intensa correspondência, Higginson não se contenta com a escrita de Emily e mantém intacta a curiosidade sobre sua imagem e o desejo de conhecê-la pessoalmente, que, quando finalmente satisfeito, veremos, ainda assim não apazigua seu tormento diante daquela criatura. Mais de uma vez, sugere que ela vá encontrá-lo em Boston. Aqui, Emily responde a uma carta em que Higginson provavelmente a chama de "evasiva":

Querido amigo.

Quem meu Cão conheceu não poderia escapar ao outro.

Ficaria feliz em lhe ver, mas seria um prazer espectral - a não se realizar. Não tenho certeza sobre Boston.

Tinha prometido visitar meu Médico por uns dias em maio, mas o Pai se opõe, pois se acostumou a minha presença.

É muito mais longe até Amherst?

O senhor encontraria uma pequena Anfitriã mas uma grande Acolhida -

Para que o senhor não encontre minha Serpente e pense que o engano no fato de ela ter sido roubada - derrotada também na terceira linha pela pontuação. A terceira e a quarta eram uma só - eu lhe disse que não publicava - temia que me achasse pretensiosa. Se eu ainda insistir que o senhor me ensine, não ficaria muito chateado?

Serei paciente - constante, nunca rejeitarei seu bisturi, e que a minha lentidão o instigue,

\footnotetext{
${ }^{12}$ Carta 268, em julho de 1862.

${ }^{13}$ Emily teria apenas um retrato seu, um daguerreótipo aos 17 anos, da época de escola, que tornou-se famoso e é exibido em quase todas as publicações sobre a escritora.
} 
o senhor que antes de mim soube que

Exceto as de pequeno porte

Nenhuma vida é redonda -

Estas - rápido tornam-se esfera

E ali se findam -

As maiores - crescem devagar

E mais tarde pendoam

Os Verões das Hespérides

Mais tempo perduram.

Dickinson $^{14}$

Em junho de 1866, uma nova recusa - e um novo convite: "Devo esquecer Boston. O Pai prefere assim. Ele gosta que eu viaje com ele, mas é contra eu fazer visitas. Poderia eu insistir para que seja meu Convidado no Pouso de Amherst? Quando tiver lhe visto, aperfeiçoar será ainda melhor prazer, pois que deverei saber quais são os enganos." 15

Após sua segunda recusa parece ter havido um lapso na correspondência dos dois, que viria a ser interrompido com a breve nota por parte de Emily, no ano seguinte: "Trazendo ainda meu apelo pela Cultura. Esta me ensinaria agora?"16 Essa clara referência ao artigo de Higginson intitulado "Um apelo pela cultura", publicado em janeiro de 1867 no Atlantic Monthly, juntamente com a data de postagem, é o que determina a data atribuída a essa carta, além da caligrafia, como em todas as cartas não datadas ou com a data não preservada. $O$ fato é que os lapsos na correspondência, bem menores e menos frequentes a partir de 1870 , podem se dever tanto à questão da preservação do material mais antigo quanto a questões de ordem pessoal de Emily - momentos em que a escritora teria se retraído e espaçado o contato com os amigos, como quando de tratamentos de saúde ou da morte de seu cão, que a levou a retomar a correspondência com Higginson, aparentemente após dezoito meses de silêncio: "Carlo morreu - E. Dickinson. O senhor me ensinaria agora?"17

Dessa forma, temos de tirar nossas próprias conclusões - ou não - do fato de a próxima carta a Higginson preservada, após aquela segunda recusa de Emily em ir a Boston, ser de quase dois anos depois, quando a escritora responde à seguinte carta de seu preceptor:

Às vezes tomo suas cartas e versos, querida amiga, e quando sinto seu estranho poder, não é estranho que encontre dificuldade em escrever e que longos meses se passem. Tenho grande desejo de lhe ver, sentindo sempre que quem sabe se eu pudesse uma vez tomarlhe pelas mãos eu poderia ser algo para você; mas até então você só se envolve nessa ardente névoa e eu não posso alcançá-la, mas apenas me alegro com as raras faíscas de luz. Todo ano penso que inventarei algum jeito de ir a Amherst e vê-la: mas é difícil, pois sou sempre obrigado a viajar para palestras, e raramente posso viajar por prazer. Ficaria feliz de ir a Boston, a qualquer tempo possível, para encontrá-la. Sou sempre o mesmo em relação a você, e nunca diminui meu interesse naquilo que me envia. Gostaria de ter

\footnotetext{
${ }^{14}$ Carta 316, do início de 1866.

${ }^{15}$ Carta 319, em 9 de junho de 1866.

${ }^{16}$ Carta 323, em julho de 1867.

${ }^{17}$ Carta 314, em janeiro de 1866.
} 
notícias suas com freqüência, mas me retraio para que o que eu escreva não seja mal calculado e eu perca o fino limite de pensamento a que você beira. Seria tão fácil, eu temo, perdê-la. Mas ainda assim, veja, eu tento. Penso que se eu pudesse uma vez vê-la e saber que é real, eu poderia me sentir melhor. (...) É difícil para mim entender como pode viver tão sozinha, com pensamentos de tal qualidade vindo a você e mesmo privada da companhia de seu cão. Embora isso pudesse impedir qualquer um de pensar além de um certo ponto e ter tais luminosos flashes como acontece a você - então talvez o lugar não faça muita diferença.

Você não viria a Boston vez ou outra? Todas as senhoras o fazem. Imagino se seria possível seduzi-la aos encontros da $3^{\underline{a}}$ segunda do mês, na casa da Sra. Sargent à rua Chestnut, $\mathrm{n}^{\circ}$ 13 , às 10 da manhã - quando alguém lê um texto e os outros conversam ou escutam. Na próxima segunda a Sra. Emerson lê e então às 3 e meia da tarde há um encontro no Clube das Senhoras em Tremont Place, 3, onde lerei um trabalho sobre as deusas gregas. Seria um bom momento para você vir, embora eu prefira que venha num dia em que eu não esteja tão atarefado - já que meu objetivo é muito mais vê-la que entretê-la. Também estarei em Boston durante a semana do meu aniversário, de $25 *$ a 28 de junho - ou quem sabe o Festival de Música, também em junho, tentaria você. Veja que falo a sério. Ou não precisa da brisa do mar no verão? Escreva e conte qualquer coisa em prosa ou verso, e serei menos melindroso no futuro, e mais desejoso de escrever-lhe canhestras linhas ao invés de nenhuma.

Sempre seu amigo

* Há um encontro extra na casa da Sra. Sargent nesse dia e o Sr. Weiss lerá um ensaio. Tenho direito de convidá-la e garanto que você pode simplesmente bater e entrar. ${ }^{18}$

Temos então a resposta de Emily, com sua terceira recusa a ir a Boston e o terceiro convite a Higginson, para que a visitasse em Amherst:

Querido amigo

Uma carta sempre me toca como a imortalidade, pois é a mente apenas sem o amigo em corpo. Em dívida em nossa conversa com a atitude e o tom, parece haver no pensamento um poder espectral que caminha sozinho - gostaria de agradecer-lhe pela sua grande gentileza, mas nunca tento erguer palavras que não posso carregar.

Se o senhor viesse a Amherst, talvez eu pudesse melhorar, embora a Gratidão seja a tímida riqueza daqueles que nada têm. Estou certa de que fala a verdade pois que os nobres assim fazem, mas suas cartas me deixam sempre surpresa. Minha vida tem sido simples e dura demais para perturbar alguém.

"Olhada pelos anjos", sem ser de todo minha responsabilidade.

É difícil não se tornar ficcional em um lugar tão belo, mas os mais severos testes são permitidos.

Quando Menina me lembro de ouvir aquela notável passagem e de escolher o "Poder," não sabendo naquela época que "Reino" e "Glória" estavam incluídos.

O senhor observou o fato de eu viver sozinha - para um Desterrado, todo País é inútil exceto o seu. O senhor fala com carinho em me ver. Se fosse por favor da sua conveniência vir tão longe como a Amherst eu ficaria muito feliz, mas não atravessarei o chão de meu Pai para alcançar nenhuma Casa ou cidade.

De nossos maiores atos somos ignorantes -

O senhor não tem consciência de que salvou minha Vida. Agradecer-lhe pessoalmente tem sido, desde então, um de meus poucos desejos. A criança que pede minha flor "Você me dá," - diz ela - "me dá?" - não conheço outra forma de pedir o que desejo.

O senhor me desculpe cada uma dessas palavras, porque ninguém me ensinou outras?

Dickinson $^{19}$

${ }^{18}$ Carta 330a, de 11 de maio de 1869.

${ }^{19}$ Carta 330, em junho de 1869. 
Pois bem. Dessa forma, em 1870, oito anos após o início da correspondência, Higginson vai vê-la em Amherst. O encontro é para ele tão marcante que o registra por inteiro em seu diário e em cartas para sua esposa e irmã. Entretanto, nem mesmo estando diante dela consegue apreender a escritora, como entrevemos nessa carta à esposa, escrita logo depois do encontro:

Não devo ficar a noite toda lhe escrevendo tudo sobre E. D. querida (sic), mas se você tivesse lido os romances da Sra. Stoddard entenderia uma casa onde cada membro cuida de sua própria vida. Contudo, eu vi apenas ela. (...)

Um passo de criança na entrada e de repente uma mulher pequena e comum, com os cabelos avermelhados e cheios repartidos e o rosto parecido com o da Belle Dove, não menos - com nenhum belo traço - em um simples e primorosamente branco pique e um xale de malha de lã penteada azul. Ela veio até mim com dois lírios que colocou de forma infantil em minha mão dizendo: "São minha apresentação", com uma voz de criança, suave e sem fôlego, e meio amedrontada - acrescentando entre a respiração Desculpe se estou assustada; nunca vejo estranhos e quase não sei o que dizer - mas então falou rápido e a partir daí sem parar - respeitosamente - às vezes parando para pedir que eu falasse em seu lugar - mas prontamente recomeçando. Algo entre Angie Tilton e Mr. Alcott, mas completamente sincera e simples, dizendo muitas coisas que você acharia tolas e eu sábias - e algumas coisas que você teria gostado. Reproduzo algumas aqui. (...) "Mulheres falam: homens são calados: por isso temo as mulheres."

"Meu pai lê apenas aos domingos - ele lê livros solitários e rigorosos."

"Se eu leio um livro e ele torna meu corpo tão frio que nenhum fogo é capaz de aquecêlo, sei que aquilo é poesia. Se sinto fisicamente como se o topo da minha cabeça estivesse a ser arrancado, sei que aquilo é poesia. São as únicas maneiras de saber. Existe alguma outra?"

"Como a maioria das pessoas vive sem nenhum pensamento? Existem muitas pessoas no mundo (deve ter notado nas ruas) Como elas vivem? Como têm forças para se vestir de manhã?"

"Quando perdi o uso de meus Olhos foi um conforto pensar que existiam tão poucos livros de verdade que eu acharia facilmente alguém para os ler pra mim."

"A verdade é uma coisa tão rara que é delicioso dizê-la."

"Encontro êxtase na vida. A mera sensação de viver é alegria bastante."

Perguntei a ela se nunca sentia falta de uma ocupação, nunca saindo de casa e nunca vendo visitas "Eu nunca pensei em conceber que eu pudesse algum dia ter a menor aproximação de tal falta por toda a minha existência" (e completou) "Sinto que não fui clara o suficiente." $(. . .)^{20}$

Higginson vai em busca de um retrato de sua correspondente, mas só o que consegue é relatar, extasiado, os momentos fugidios em que com ela esteve - uma cor, uma sensação, uma respiração, um movimento - e repetir, sem palavras, as dela que para sempre ecoariam em sua memória. No dia seguinte, escreve novamente à esposa, dizendo ter saudades e lamentar sua ausência, acrescentando que ela provavelmente detestaria a viagem. Talvez para justificar tamanho entusiasmo em transcrever as falas de E. D., confessa estar feliz em não viver junto de quem profere afirmações como as registradas:

"O senhor poderia me contar como é uma casa."

"Nunca tive uma mãe. Suponho que mãe seja alguém para quem você corre quando tem problemas." (...)

\footnotetext{
${ }^{20}$ Carta 342a, de 16 de agosto de 1870 . (Tradução minha)
} 
"Será esquecimento ou absorção quando as coisas abandonam nossa mente?" (...)

Quando eu disse que voltaria em algum tempo ela disse "Diga daqui a muito tempo, será mais perto. Algum tempo é nada." (...) Eu nunca estive com alguém que sorvesse tanto a minha energia nervosa. Sem tocá-la, ela me sugava. Fico contente de não viver perto dela. Ela sempre me achava cansado, parecia pensar muito nos outros. ${ }^{21}$

Vinte anos depois, a escritora ainda é um enigma para Higginson, o que ele registra no Atlantic Monthly LXVIII, em outubro de 1891:

A impressão indubitavelmente em mim causada foi de um excesso de tensão, e de uma vida anormal. Talvez na época eu pudesse ter ido além daquela relação de certo modo excessivamente tensa que não a minha vontade, mas suas necessidades, tinham nos imposto. Certamente eu teria sido mais feliz se a tivesse trazido para o nível da simples verdade e da camaradagem diária, mas não era de todo fácil. Ela era um ser enigmático demais para que eu a decifrasse em uma hora de entrevista, e o instinto me disse que a menor tentativa de uma investigação direta faria com que ela se recolhesse em sua concha; eu podia apenas sentar quieto e observar, como se faz na selva; devo nomear meu pássaro sem uma arma, recomenda Emerson. ${ }^{22}$

Bem, se Higginson reconheceu não ter conseguido penetrar no mundo de E. D. e ele tentou - não podemos partir para uma leitura de suas cartas que pretendesse sua decifração, ou mesmo uma "reconstituição" de sua vida. Sabemos que devemos resistir a tal impulso em favor de perceber traços de sua vida-escrita, ${ }^{23}$ biografemas, retratos formados a partir de "cavacos de lembranças, a erosão que só deixa da vida passada alguns vincos", nas palavras de Roland Barthes:

Se eu fosse escritor, já morto, como gostaria que a minha vida se reduzisse, pelos cuidados de um biógrafo amigo e desenvolto, a alguns pormenores, a alguns gostos, a algumas inflexões, digamos: "biografemas", cuja distinção e mobilidade poderiam viajar fora de qualquer destino e vir tocar, à maneira dos átomos epicurianos, algum corpo futuro, prometido à mesma dispersão; uma vida furada, em suma, como Proust soube escrever a sua na sua obra, ou então um filme à moda antiga, de que está ausente toda palavra e cuja vaga de imagens (...) é entrecortada, à moda de soluços salutares, pelo negro apenas escrito do intertítulo, a irrupção desenvolta de outro significante: o regalo branco de Sade, os vasos de flores de Fourier, os olhos espanhóis de Inácio. ${ }^{24}$

As vestes brancas, o cabelo do Ouriço, o quarto e o Cão, o retrato único de Emily: biografemas da própria falta, vestígios da ausência. A partir de um desses traços - o traço da escrita - é que se pretende apresentar a escritora. É a partir do biografema da própria escrita - a cômoda cheia de pacotinhos -, da própria experiência literária de Emily que poderemos aprender um modo de ler a escritora. Assim, longe de tratar suas cartas como portais de acesso à vida para a compreensão da obra, só o que podemos é tomar desde já suas cartas como obra, pois que, enfim, toda a sua obra se escreve - se inscreve - como carta - sua carta ao mundo.

\footnotetext{
${ }^{21}$ Carta 342b, de 17 de agosto de 1870. (Tradução minha)

${ }^{22}$ DICKINSON. Selected Letters, p. 211. (Tradução minha)

${ }^{23}$ Ruth Silviano Brandão cunha o termo em seu livro A vida escrita (7 Letras, 2006). Silvina Rodrigues Lopes já se referira algumas vezes à "relação vida-escrita". Aqui, opto pelo nome composto "vida-escrita".

${ }^{24}$ BARTHES. Sade, Fourier, Loyola, p. 12.
} 
Retomemos então a questão das cartas. Segundo Silvina Rodrigues Lopes, o espaço da carta - principalmente daquela de artistas e pensadores, pelo seu evidente valor intelectual - é um espaço múltiplo, no qual pensamento e poesia se encontram. Contudo, o que mais interessa à autora, e que está além desse estatuto múltiplo da carta, é:

Aquilo em que a leitura de uma correspondência pode ser importante por mostrar a construção de uma margem onde o escritor toma consciência da fragilidade da relação eu-outro e, sobretudo, do seu apagamento na passagem à escrita literária, na exacta medida em que nela o "autobiográfico" - a escrita de si - é profundamente antiautobiográfico, entendida a autobiografia como narração e descrição de factos e relações. ${ }^{25}$

Além disso, Silvina aponta uma "dimensão autobiográfica" que nada teria a ver com o gênero autobiográfico, e diz que é naquela dimensão que a literatura evidencia a estrutura intersubjetiva da destinação epistolar: "É nesse sentido que se pode dizer que todos os textos literários se constituem como 'cartas' para nada (o que não significa que sejam para o vazio), 'textos para nada' (Beckett). Por isso, não têm destinadores nem destinatários."26

Então, para que Emily escreve cartas? Para quem? - poderíamos nos perguntar, especialmente no caso de Higginson, já que a correspondência entre os dois seria parte de uma tutela, que supostamente habilitaria Emily a finalmente publicar - o que jamais acontece. Quem é esse interlocutor que, mesmo impressionado com a qualidade da escrita de Emily, se interpõe entre ela e o público? Para que Emily continua a lhe escrever? Se não há um objetivo, há um motivo: porque, sabia Emily, não é para um outro que se escreve. Porque, sabia também, com Marguerite Duras, que não se pode escrever.

Escrever.

Não posso.

Ninguém pode.

É preciso dizer: não se pode.

E se escreve. ${ }^{27}$

E Dickinson escreve. É precisamente por isso que escreve. Porque sabe que, de alguma forma, não é ela que escreve: "Quando me coloco, a mim mesma, como a Representante do Verso - isto não quer dizer - eu - mas uma pessoa suposta." Blanchot comenta essa passagem do "eu" ao "ele" na escrita a partir da obra de Kafka, distinguindo este "ele", que designa como "neutro", do "ele" correspondente ao outro interlocutor na instância discursiva:

Quando escrever é entregar-se ao interminável, o escritor que aceita sustentar-lhe a essência perde o poder de dizer "Eu". (...) O "Ele" que toma o lugar do "Eu", eis a solidão que sobrevém ao escritor por intermédio da obra. "Ele" não designa o interesse objetivo, o desprendimento criador. "Ele" não glorifica a consciência em um outro que não eu, o impulso de uma vida humana que, no espaço imaginário da obra de arte, conservaria a

\footnotetext{
${ }^{25}$ LOPES. Literatura, defesa do atrito, p. 137.

${ }^{26}$ LOPES. Literatura, defesa do atrito, p. 137.

${ }^{27}$ DURAS. Escrever, p. 47.
} 
liberdade de dizer "Eu". "Ele" sou eu convertido em ninguém, outrem que se torna o outro, e que, no lugar onde estou, não possa mais dirigir-se a mim e que aquele que se me dirige não diga "Eu", não seja ele mesmo. ${ }^{28}$

O que conduz "à despossessão, à experiência do desaparecimento, ao abandonarse a si mesmo e entrar no espaço da ficção, ou da literatura". ${ }^{29}$ Silvina toca este ponto da escrita em que ela se dá pelo desaparecimento do sujeito, citando as palavras de Aldo Gargani:

Escrevo para me aniquilar, escrevo linhas para me reduzir a um ponto, para que finalmente se manifeste a esperança que se exprime apenas por si e que não posso, que ninguém a si pode dar (...). Eu, cada qual, sou, somos o ponto do desenraizamento e do embate entre um mundo que se desvanece e outro que se desenha na deriva da sua instabilidade, e é toda a realidade não pressagiada e incalculável..$^{30}$

Para Blanchot, a origem da obra se dá nesse momento em que o escritor se abandona à sua solidão, em que a despossessão do sujeito dá lugar à sua ocupação pelo exterior "O meu pensamento abandona-me em todos os graus,"31 diz Artaud, ecoando Emily: "Is it oblivion or absorption when things pass from our minds?"32

Para Emily, desterrada, estrangeira, é na escrita, no seu próprio desaparecimento que se dá na escrita, que ela realiza o agir impessoal, o neutro, o "tornar-se presença" de que fala Gargani: "Na espoliação de nós, que é um por em acção de nós mesmos, tornamo-nos a nossa própria presença, precisamente a presença estreme que rodeia nossa situação de radical solidão." ${ }^{33}$

Silvina Lopes, ao comentar as cartas de Van Gogh a seu irmão, destaca uma, na qual "do que se trata é também de manter a ligação que impede o mundo de deslizar para o insuportável":

Não posso imaginar que poderia viver de outra maneira; não aspiro sequer a ser desembaraçado das minhas dificuldades e preocupações; a única esperança que alimento é que estas dificuldades e preocupações se me não tornem insuportáveis. Isso não acontecerá enquanto puder trabalhar e alegrar-me com a simpatia que me testemunham homens como tu. ${ }^{34}$

É também por isso que Emily escreve, e escreve cartas. Sabe da fragilidade da relação eu-outro - do apagamento mesmo do eu na escrita, bem como da inexistência do outro do discurso, e, nas palavras de Silvina Lopes, "se o outro nunca esteve lá para onde dirigimos a palavra isso implica uma solidão tão radical que corresponde à perda

\footnotetext{
${ }^{28}$ BLANCHOT. O espaço literário, p. 17,19.

${ }^{29}$ LOPES. Literatura, defesa do atrito, p. 148.

${ }^{30}$ LOPES. Literatura, defesa do atrito, p. 138-139.

${ }^{31}$ Citação de trecho de carta de Artaud a Jacques Rivière, em 1923.

${ }^{32}$ Vimos essa frase traduzida na carta 342b, em que Higginson relata à esposa trechos de sua conversa com E. D.

${ }^{33}$ LOPES. Literatura, defesa do atrito, p. 139.

${ }^{34}$ LOPES. Literatura, defesa do atrito, p. 143-144.
} 
da palavra própria, palavra que antes de mais deveria ter vindo do outro". ${ }^{35}$ Ainda assim, ou precisamente por isso, procura - se não comunicar - conectar-se com os que amava, e com o mundo, de uma certa forma. Esse mundo que muitos dizem Emily não ter conhecido foi por ela escrito em suas cartas e poemas, e sua relação com ele e as pessoas era mais forte do que se poderia achar, a julgar apenas por sua reclusão. Higginson notou sua preocupação com os outros, quando esteve com ela, e sua necessidade e tentativa de contato, ainda que com um ramo de flores ou uma porta entreaberta a se interpor, o que é fácil perceber em cartas como esta:

\section{Querido Mestre}

Estou doente, mas, mais aflita porque está doente, faço o meu mais pesado trabalho manual longo o suficiente para lhe dizer. Pensei que talvez estivesse no Céu, e quando falou novamente, pareceu-me tão doce, e maravilhoso, e tanto me surpreendeu - queria que estivesse bem.

Queria que todos os que amo nunca mais estivessem frágeis. (...)

Cada Sábado no Mar me faz contar os Sábados até nos encontrarmos na costa - e (estarão) se estiveram as colinas tão azuis como dizem os marinheiros. Não posso mais falar (ficar mais) esta noite (agora), pois esta dor me proíbe.

Que forte e frágil é recordar, e fácil, absolutamente, amar. Queira me dizer, por favor, diga-me assim que estiver bem. ${ }^{36}$

De fato, muitos já se perguntaram, com estranheza, como ela podia escrever, sem ter "nenhuma experiência", subestimando a vida que Emily supostamente levava: sem graça, sozinha. Contudo, não é assim que Emily se mostra em relação à vida. Ao contrário, sempre mostra um prazer - I find ecstasy in living - um contentamento - the mere sense of living is joy enough -, algo que ela pôde aproveitar talvez principalmente após o "controle" de que fala, e que foi trazido pela correspondência com Higginson, aquele que a tolhia mas ao mesmo tempo lhe permitia ser ela mesma, na esfera íntima das cartas, que eventualmente trouxeram o belo pensamento: "Existence has overpowered Books." 37

Pensava que ser um Poema impedisse de se escrever poemas, mas percebo o Engano. Foi como voltar à Casa, ver seu belo pensamento uma vez mais, agora há muito interdito - o Intelecto é o que o Patriota quer dizer quando fala de sua "Terra Natal"? Eu deveria ter medo de "citar" aquilo que o senhor "mais valoriza."

O senhor experimentou a santidade.

Não foi por mim tentada.

Da Vida possuir -

Da Vida retirar -

Mas nunca a Reserva tocar -

O senhor pergunta gentilmente por minhas Flores e Folhas - tenho lido muito pouco ultimamente - a Existência dominou os Livros. Hoje, matei um Cogumelo -

\footnotetext{
${ }^{35}$ LOPES. Literatura, defesa do atrito, p. 147.

${ }^{36}$ Carta 187, por volta de 1858. Esta é uma das três "cartas ao mestre", o qual especula-se que seja o Reverendo Charles Wadsworth, tendo sido encontrada entre os papéis de E. D. Uma cópia provavelmente foi enviada ao destinatário, pois parece claro que se trata de uma resposta.

${ }^{37}$ Vemos uma posição semelhante em André Comte-Sponville, que em O amor e a solidão por mais de uma vez declara ter consciência da soberania da vida em relação à literatura, pensamento que se tornava tanto mais claro quanto maior sua experiência de escrita.
} 
Senti que a relva gostara

De tal interrupção.

Esse Rebento Secreto

Circunspeto do Verão.

As palavras mais vastas são tão estreitas que podemos facilmente atravessá-las - mas há águas mais profundas que aquelas sem Ponte. Meus Irmãos adorariam vê-lo. Duas vezes, o senhor partiu - Mestre -

Não viria apenas mais uma vez? $-^{38}$

Para manter contato com esse mundo, precisava de um mestre. Foi sempre afeita a eles, como escreve aos 17 anos, na expectativa de entrar para o Seminário: "I am always in love with my teachers." Thomas H. Johnson comenta:

A expressão tem aquela qualidade de candura e precisa auto-avaliação que dá a Emily Dickinson estatura como pessoa e como poeta. Por toda a sua vida ela procurou pela liderança de um "mestre." A partir de 1862, Higginson ocupou esse lugar para ela, como todas as suas cartas a ele deixam claro. Certamente esse era seu sentimento em relação ao Dr. Wadsworth, e quem sabe outros, agora jamais sabidos. Mas a necessidade de um tutor ou guia, que poderia conduzi-la à maneira de Dante pelas visões de uma divina comédia, é a extensão lógica de toda pessoa sensível, e especialmente necessária aos poetas, que procuram traduzir a humanidade para pastagens mais verdes, através da linguagem. A busca de Emily Dickinson por um guia, ela a expressou com admirável franqueza a Higginson em agosto de 1862. Sem reticências e com clara auto-análise ela disse: "Não tenho Monarca em minha vida, e não posso me governar, e quando tento me organizar explodem-se minhas pequenas Forças - e fico a descoberto -" ${ }^{39}$

Talvez por isso Emily continue a pedir a tutela de Higginson. Aceitou ser guiada por ele, mesmo se sabendo incompreendida, pois parecia saber ser essa a condição inelutável do ser humano. Renunciou à publicação em favor da escrita, desse contato com o mundo que poderia ter em vida - sua ordem-descalça. Seu nascimento como poeta nasce justamente com sua renúncia à fama; é o seu desaparecimento como autora que dá lugar ao surgimento da obra - seu livro por vir. E, por isso, várias vezes, e de diversas formas, ela diz de sua gratidão a Higginson: Gratitude is the only secret that cannot reveal itself, ${ }^{40}$ You were not aware that you saved my Life - convicção esta provavelmente muito forte, visto que E. D. usaria a mesma expressão em outra carta a Higginson, dez anos depois. ${ }^{41}$

Da mesma forma, Emily Dickinson procura seu ponto de contato com o mundo através dos amigos - poucos, mas constantes durante toda sua vida - que, lançando-se também à escrita das cartas, davam a Emily o material sobre o qual construir sua vidaescrita, e o modo de fazê-la sentir-se parte de um mundo e um tempo tão fictícios quanto pareciam ser-lhes aqueles em que vivia. "O que importa é que se tenha escolhido a forma-carta enquanto forma de resposta a uma amizade, pois isso assinala que se é

\footnotetext{
${ }^{38}$ Carta 413, no fim de maio de 1874.

${ }^{39}$ DICKINSON. Selected Letters, p. xi. (Tradução minha)

${ }^{40}$ DICKINSON. Selected Letters, p. 209. Carta 342b, de Higginson à esposa, em que registra essa frase que E. D. lhe teria dito em sua partida.

${ }^{41}$ DICKINSON. Selected Letters, p. 197. Vimos essa frase na carta 330, aqui traduzida.
} 
ainda parte de uma comunidade." ${ }^{42}$ Essa comunidade, Emily soube reinventá-la na escrita, criando, na verdade, uma que transcenderia o breve espaço de tempo de sua existência: A letter always feels to me like immortality because it is the mind alone without corporeal friend. ${ }^{43}$

E nós, parte dessa imortalidade, dessa comunidade, somos também convidados a ler sua letter e, longe de estranhá-la, partilhar de sua estrangeiridade, tornarmo-nos nós mesmos estrangeiros, desenraizados, desertados num sem-tempo, sem-lugar, que é a terra da escrita.

Esta é minha carta ao Mundo Que nunca escreveu a Mim As simples Novas que a Natureza contou Com suave Majestade

Sua Mensagem é para aqueles

Cujas Mãos não posso ver -

Por amor a Ela - Caros - Confrades -

Julguem brandamente - meu Ser ${ }^{44}$

\section{(4)}

\section{A B S TRACT}

Departing from the first letter Emily Dickinson (1830-1886) wrote Thomas Higginson, who would forever be her "preceptor" and interlocutor, this text proposes a reading of the Northamerican writer considering the notion of biografema and the idea of her work as "letter to the world" - according to one of her most famous poems -, with all the implications brought by the term and under the light of the theories of Roland Barthes, Maurice Blanchot e Silvina Rodrigues Lopes, among others.

\section{KEYWORDS}

Poetry, writing, letter

\section{REFERÊNCIAS}

BARTHES, Roland. Sade, Fourier, Loyola. São Paulo: Brasiliense, 1990.

BLANCHOT, Maurice. O livro por vir. Lisboa: Relógio d'Água, 1984.

BLANCHOT, Maurice. O espaço literário. Rio de Janeiro: Rocco, 1987.

COMTE-SPONVILlE, André. O amor a solidão. São Paulo: Martins Fontes, 2006.

\footnotetext{
${ }^{42}$ LOPES. Literatura, defesa do atrito, p. 150.

${ }^{43}$ Essa frase, que já vimos traduzida na carta 330, e que E. D. escreve a Higginson em 1869, ela a ecoaria bem mais tarde, em 1882, em carta ao amigo James Clark, que era amigo de Charles Wadsworth, e com quem iniciou correspondência após a morte deste último, o suposto "master" das correspondências.

${ }^{44}$ Poema 441: "This is my letter to the World / That never wrote to Me - / The simple News that Nature told - / With tender Majesty // Her Message is committed / To Hands I cannot see - / For love of Her - Sweet - countrymen - / Judge tenderly - of Me"
} 
DICKINSON, Emily. Selected Letters. Ed. Thomas H. Johnson. Cambridge/London: The Belknap Press of Harvard University Pres, 1986.

DICKINSON, Emily. The Complete Poems of Emily Dickinson. Ed. Thomas H. Johnson. Boston/New York/London/Toronto: Litle, Brown and Company, 1960.

DURAS, Marguerite. Escrever. Rio de Janeiro: Rocco, 1994.

JOHNSON, Thomas H. Introduction. In: DICKINSON, Emily. The Complete Poems of Emily Dickinson. Ed. Thomas H. Johnson. Boston/New York/London/Toronto: Litle, Brown and Company, 1960. p. v-xi.

LISPECTOR, Clarice. Água viva. Rio de Janeiro: Francisco Alvim, 1994.

LOPES, Silvina Rodrigues. Literatura, defesa do atrito. Lisboa: Vendaval, 2003.

WOOLF, Cynthia Griffin. Emily Dickinson. New York: Wesley Publishing Company INC, 1996. 